\title{
PERBANDINGAN MUTU ANTARA MORTAR PASANGAN BATA KOMPOSISI 1 KAPUR : 2 SEMEN MERAH : 3 PASIR DENGAN MORTAR PASANGAN BATA KOMPOSISI 1 SEMEN PORTLAND : 4 PASIR
}

\author{
Maya Fajriana, Prihantono, Nira Nasution
}

\begin{abstract}
The purpose of this research is to determine the comparison of quality (compressive strength and shear strength) between mortar with the composition of 1 Lime : 2 Red Cement : 3 Sand and mortar with the composition of 1 Portland Cement : 4 Sand for masonry.

This research took place in The Hall of Material and Technical Goods Laboratory of Dinas Perindustrian dan Perdagangan DKI Jakarta, Letjen Suprapto Street Cempaka Putih, Central Jakarta. This research was conducted during December 2006 to April 2007.

The method of this research is experiments, the population of sample being tested is 60pcs, which is 30pcs for compressive strength test and 30pcs for shear strength test. Samples taken for analysis is 40pcs, which is 20pcs for compressive strength test, and 20pcs for shear strength test. The Sample picking method is a simple randomly picked method.
\end{abstract}

The test result for mortar with the composition of 1 Lime : 2 Red Cement : 3 Sand produced average compressive strength of $7.59 \mathrm{Mpa}$ and average shear strength of $0.18 \mathrm{Mpa}$, while mortar with the composition of 1 Portland Cement : 4 Sand produced average compressive strength of $32.34 \mathrm{Mpa}$ and average shear strength of $0.45 \mathrm{Mpa}$.

The result of this research is that mortar with the composition of 1 Lime : 2 Red Cement : 3 Sand have the lower compressive and shear strength compared to mortar with composition of 1 Portland Cement : 4 Sand.

\section{PENDAHULUAN}

Dewasa ini dunia konstruksi Indonesia khususnya Jakarta, tengah berkembang dengan pesat. Indikasinya dapat dilihat dengan maraknya proyek pembangunan di kota ini mulai dari pembangunan perumahan, ruko, pusat perbelanjaan, hotel hingga gedung perkantoran yang berpuluh-puluh lantai.

Salah satu komponen dari bangunan yang penting adalah dinding. Hampir pada semua tipe bangunan dengan berbagai fungsi terdapat dinding sebagai elemennya. Dinding berfungsi 
sebagai media pemisah / penyekat ruangan satu dengan ruangan yang lain, pembatas antara ruangan dalam dan ruangan luar dan ada juga dinding yang berfungsi sebagai pemisah sekaligus penahan beban. Oleh sebab itu dinding harus memenuhi persyaratan teknis yang telah ditentukan untuk memenuhi kriteria layak dari bangunan.

Sebagian besar masyarakat saat ini masih menggunakan bata merah sebagai bahan bangunan yang digunakan untuk komponen dinding bangunan tingkat rendah maupun tingkat tinggi, sehingga kebutuhan bata merah pada saat ini masih tergolong cukup tinggi. Sesuai dengan kemajuan ilmu dan teknologi dewasa ini banyak bermunculan bahan bangunan untuk pembuatan dinding, namun bata merah mempunyai kelebihan tersendiri bila dibandingkan dengan bahan lainnya.

Sebuah dinding bata merah tidak terlepas dari mortar atau spesi yang mengikat tiap bagian bata secara bersamaan. Walaupun penggunaan mortar hanya terdapat sebesar $7 \%$ dari total volume pekerjaan batu, akan tetapi pengaruhnya dirasakan sangat jauh lebih besar dari presentase volumenya. Proporsi mortar relatif kecil pada pasangan batu bata

Mortar atau spesi pada dasarnya berguna sebagai bahan pengisi dan sebagai bahan perekat bata satu dengan bata yang lain sehingga terbentuk suatu pasangan yang kukuh. Mortar yang memenuhi ketentuan spesifikasi proporsi harus terdiri dari bahan bersifat mengikat, agregat dan air yang seluruhnya harus memenuhi persyaratan.

Pada zaman dahulu sebelum ditemukan semen portland, masyarakat memanfaatkan puing bata merah yang pecah pada waktu proses pembakaran yang kemudian digiling atau ditumbuk sampai halus. Puing bata merah tersebut dinamakan semen merah.

Di pulau Jawa semen merah umumnya diperdagangkan dan mudah diperoleh serta relatif murah dibandingkan dengan semen portland (PC). Semen merah juga lazim digunakan untuk campuran bentuk mortar atau spesi. Dan berdasarkan pengetahuan yang didapat dari beberapa sumber ternyata semen merah mengandung unsur silika ( $\mathrm{Si}$ ) yang cukup besar, silika mempunyai manfaat positif terhadap campuran mortar yaitu sebagai pengikat. Apabila kapur padam dicampur dengan semen merah akan membentuk semen yang dikenal dengan nama semen pozzolan. 
Mutu dan karakteristik mortar bergantung dari bahan-bahan penyusunnya. Oleh karena itu penulis tertarik untuk melakukan penelitian perbandingan kuat tekan dan kuat geser antara mortar komposisi kapur, semen merah dan pasir dengan mortar komposisi semen portland dan pasir untuk pasangan bata.

\section{METODA}

Tujuan penelitian ini adalah :

1. Mengetahui perbedaan kuat tekan antara mortar komposisi 1 kapur : 2 semen merah : 3 pasir dengan mortar komposisi 1 semen Portland : 4 pasir

2. Mengetahui perbedaan kuat geser antara mortar pasangan bata komposisi 1 kapur : 2 semen merah : 3 pasir dengan mortar pasangan bata komposisi 1 semen Portland : 4 pasir

Tempat penelitian untuk pembuatan dan pengujian dilaksanakan di Labolatorium Balai Bahan dan Barang Teknik Dinas Perindustrian dan Perdagangan Propinsi DKI Jakarta, Jl. Letjen Suprapto Cempaka Putih Jakarta Pusat.

Waktu penelitian dilaksanakan dari bulan Desember 2006 sampai dengan bulan Mei 2007.

Metode yang digunakan pada penelitian ini menggunakan metode eksperimen Populasi dalam penelitian ini terdiri dari 2 kelompok benda uji. Tiap kelompok benda uji diperlakukan komposisi yang berbeda-beda, yaitu mortar dengan komposisi campuran semen merah, kapur, pasir dan mortar dengan komposisi campuran semen portland, pasir. Dan masingmasing kelompok dilakukan 2 pengujian yang berbeda, yaitu pengujian kuat tekan dan pengujian kuat geser. Tiap perlakuan sebanyak 15 buah benda uji, sehingga jumlah keseluruhan benda uji adalah 60 buah.

Sampel yang diambil untuk dianalisis adalah 40 buah, yang diambil 10 buah dari setiap kelompok benda uji. Teknik pengambilan sampel dilakukan secara acak sederhana dari masing-masing kelompok dan perlakuan. 
Variabel Penelitian

1. Variabel bebas

Variabel bebas penelitian ini yang terdiri dari komposisi campuran mortar yang dibedakan, yaitu :

a. Mortar komposisi semen merah, kapur dan pasir

b. Mortar komposisi semen portland dan pasir

2. Variabel terikat

Variabel terikat penelitian ini adalah :

1. Nilai kuat tekan dari benda uji mortar komposisi semen merah, kapur, pasir dan mortar komposisi semen Portland dan pasir untuk pasangan bata

2. nilai kuat geser dari benda uji mortar komposisi semen merah, kapur, pasir dan mortar komposisi semen Portland dan pasir untuk pasangan bata.

\section{Prosedur Kerja Labolatorium}

Prosedur kerja di laboratorium meliputi beberapa tahapan, yaitu pekerjaan persiapan, pemeriksaan bahan, pekerjaan pembuatan benda uji, pekerjaan perawatan benda uji dan pekerjaan pengujian benda uji.

\section{Pekerjaan persiapan}

Pekerjaan persiapan meliputi pekerjaan persiapan peralatan dan pengadaan bahan-bahan yang akan digunakan. Persiapan peralatan meliputi peralatan untuk pembuatan benda uji dan peralatan untuk pengujian serta mempelajari penggunaan peralatan yang diperlukan.

Persiapan bahan untuk pembuatan benda uji yaitu pengadaan semen merah, kapur, semen portland dan pasir.

\section{Pekerjaan pemeriksaan bahan}

Pemeriksaan bahan dilakukan terhadap masing-masing bahan dasar agar diketahui sifat-sifat dari bahan tersebut seperti berikut ini :

a. Pasir

1. Pengujian kadar lumpur

Prosedur pengujian kadar lumpur sesuai dengan SNI 03-1754-1990

2. Pemeriksaan zat organik dalam pasir 
Prosedur pemeriksaan zat organik dalam pasir sesuai dengan SNI 03-17551990

3. Pengujian gradasi pasir

Prosedur pengujian gradasi pasir sesuai dengan SNI 03-1968-1990

4. Pengujian indeks kekerasan butiran pasir

Prosedur pengujian indeks kekerasan butiran pasir sesuai dengan SNI 03-17561990

5. Pengujian berat jenis dan penyerapan air pasir

Prosedur pengujian berat jenis dan penyerapan air pasir sesuai dengan SNI 031970-1990

6. Pengujian kadar air pasir

Prosedur pengujian kadar air pasir sesuai dengan SNI 03-1971-1990

b. Semen Portland

Untuk semen tidak terdapat pengujian apapun karena semen yang digunakan sudah memenuhi syarat semen portland. Pada penelitian ini menggunakan semen portland tipe I cap Tiga Roda.

C. Air

Air dalam penelitian ini tidak dilakukan pemeriksaan karena air yang digunakan adalah air PAM yang telah memenuhi standar persyaratan.

d. Kapur

Pemeriksaan kapur dilakukan dengan menggunakan analisis ayakan dan diambil yang lewat saringan no. 100 seratus persen.

e. Semen merah

Pemeriksaan semen merah dilakukan sesuai dengan peraturan tras dan semen merah Indonesia NI. 20

\section{Pekerjaan pembuatan benda uji mortar}

Pembuatan benda uji mortar dengan komposisi campuran 1 kapur : 2 semen merah : 3 pasir dan komposisi campuran 1 semen portland : 4 pasir. Tiap benda uji dilakukan 2 perlakuan yaitu untuk uji tekan berbentuk kubus dengan ukuran $5 \times 5 \times 5 \mathrm{~cm}$ dan untuk uji geser berbentuk 3 buah batu 
bata yang disusun dan direkatkan dengan mortar dengan ketebalan mortar $\pm 1 \mathrm{~cm}$ membentuk suatu pasangan bata. Adapun tahapan pembuatan benda uji adalah sebagai berikut :

a. Penakaran bahan

Setelah tahap pemeriksaan bahan dilakukan, selanjutnya adalah penakaran bahan. Penakaran bahan yang digunakan dalam adukan dilakukan dengan cara ditimbang sehingga ketepatannya dapat terjamin.

b. Pencampuran bahan

Semua bahan baku yang telah ditentukan perbandingan beratnya kemudian dicampur dengan menggunakan mixer yang digerakkan dengan tenaga listrik.

c. Pencetakan atau pembuatan benda uji

Setelah pengadukan selesai, maka adukan tersebut dicetak untuk dijadikan benda uji. Untuk pengujian kuat tekan digunakan cetakan berbentuk kubus dengan ukuran $5 \times 5 \times 5 \mathrm{~cm}$. Sedangkan untuk pengujian kuat geser diperlukan 3 buah batu bata yang kemudian disusun atau direkatkan menggunakan mortar dengan ketebalan $\pm 1 \mathrm{~cm}$ sehingga terbentuk suatu pasangan batu bata.

\section{Pekerjaan pemeliharaan benda uji}

Benda uji yang telah dicetak, diberikan perawatan atau pemeliharaan sesuai dengan perlakuan masing-masing.

a. Untuk benda uji kuat tekan

Setelah mortar yang sudah dicetak didiamkan selama 24 jam dan cukup mengeras, maka mortar dilepaskan dari cetakan satu persatu kemudian mortar tersebut segera direndam dalam bak berisi air bersih pada temperatur $25^{0}$ celcius hingga berumur 28 hari.

b. Untuk benda uji kuat geser

Setelah bata disusun dan direkatkan menggunakan mortar sehingga terbentuk suatu pasangan batu bata, didiamkan selama 24 jam. Setelah mortar mengeras dan sudah mengikat tiap bagian bata, semua alat bantu dilepaskan satu persatu sehingga benda uji terlihat kukuh. Kemudian benda uji dirawat dengan cara ditutup dengan karung goni basah selama 28 hari dan kelembaban dari karung goni tersebut harus tetap terjaga. 


\section{Pekerjaan pengujian benda uji}

Pengujian kuat tekan mortar pada penelitian ini mengacu pada SNI 03-6825-2002 "Metode Pengujian Kekuatan Tekan Mortar Semen Portland" dan pengujian kuat geser mengacu pada SNI 03-4166-1996 "Metode Pengujian Kuat Geser Dinding Pasangan Bata Merah di Laboratorium". Kedua pengujian tersebut dilakukan menggunakan mesin kuat tekan merk UTM AMSLER yang mempunyai kapasitas 180.000 kgf. Hasil pengujian kuat tekan dan kuat geser mortar berupa nilai kuat tekan dan kuat geser dalam Mpa.

\section{Rancangan Penelitian}

Adapun perlakuan yang akan diberikan untuk mortar pada penelitian ini adalah sebagai berikut :

Tabel 5. Jumlah Benda Uji Tiap Kelompok

\begin{tabular}{|c|c|c|}
\hline \multirow{2}{*}{$\begin{array}{c}\text { Kelompok } \\
\text { Benda Uji }\end{array}$} & Kuat Tekan & Kuat Geser \\
\cline { 2 - 3 } & 10 buah & 10 buah \\
\hline $\mathrm{A}$ & 10 buah & 10 buah \\
\hline B &
\end{tabular}

Keterangan : $\mathrm{A}=$ mortar dengan komposisi 1 kapur $: 2$ semen merah $: 3$ pasir

$B=$ mortar dengan komposisi 1 semen portland $: 4$ pasir

\section{Populasi, sampel dan sampling}

Populasi sasaran penelitian ini adalah benda uji mortar. Terdapat 2 jenis kelompok benda uji mortar dengan komposisi yang berbeda dengan 2 perlakuan untuk tiap kelompok. Sedangkan populasi terjangkau adalah benda uji mortar tersebut sebanyak 10 buah untuk masing-masing perlakuan.

Sampel dalam penelitian ini ada 2 macam, yaitu :

1. Sampel utama, yaitu kelompok benda uji mortar yang dibuat dengan komposisi 1 kapur : 2 semen merah : 3 pasir

2. Sampel pembanding, yaitu kelompok benda uji mortar yang dibuat dengan komposisi 1 semen portland : 4 pasir. 
Instrumen penelitian yang digunakan adalah satu perangkat alat uji tekan yang telah memenuhi standar sehingga tidak memerlukan uji validitas, reabilitas dan daftar isian yang digunakan untuk mengumpulkan data.

Teknik pengambilan data dengan menggunakan metode eksperimen, data penelitian yang diambil adalah nilai kuat tekan dan kuat geser mortar dengan mesin uji kuat tekan yang telah dikalibrasi.

\section{Teknik Analisis Data Kuat Tekan Mortar}

Sebelum melakukan uji hipotesis, data kuat tekan mortar harus diuji kenormalannya menggunakan uji Lilliefors dan pengujian homogenitas menggunakan uji F. Setelah kedua persyaratan terpenuhi, selanjutnya dilakukan pengujian hipotesis menggunakan uji t "kesamaan dua rata-rata satu pihak" dengan taraf signifikan $a=0,01$

Pengujian hipotesis statistiknya ditentukan dengan :

a. $\mathrm{Ho}_{0}: \mu \mathrm{A}_{1}=\mu \mathrm{A}_{2}$

Artinya tidak terdapat perbedaan kuat tekan mortar antara mortar komposisi 1 kapur : 2 semen merah : 3 pasir dengan mortar komposisi 1 semen Portland : 4 pasir.

b. $H_{1}: \mu A_{1}<\mu A_{2}$

Artinya nilai kuat tekan mortar komposisi 1 kapur : 2 semen merah : 3 pasir lebih kecil daripada nilai kuat tekan mortar komposisi 1 semen portland : 4 pasir.

Keterangan :

$\mu A_{1} \quad$ : Nilai rata-rata kuat tekan mortar komposisi 1 kapur : 2 semen merah : 3 pasir

$\mu \mathrm{A}_{2} \quad$ : Nilai rata-rata kuat tekan mortar komposisi 1 semen portland : 4 pasir

Rumus uji t "kesamaan rata-rata satu pihak" adalah sebagai berikut :

$$
\mathrm{t}=\frac{\mathrm{XA}_{1} \mathrm{XA}_{2}}{\sqrt{\frac{\left(\mathrm{nA}_{1} 1\right) \mathrm{SA}_{1}^{2}+\left(\mathrm{nA}_{2} 1\right) \mathrm{SA}_{2}^{2}}{\mathrm{nA}_{1}+\mathrm{nA}_{2} 2}} \frac{\frac{1}{n A_{1}}+\frac{1}{\mathrm{nA}_{2}}}{}}
$$

Keterangan :

$\mathrm{t}=\mathrm{t}$ hitung

$\mathrm{XA}_{1}=$ Nilai rata-rata kuat tekan mortar komposisi 1 kapur : 2 semen merah 


\section{: 3 pasir}

$\mathrm{XA}_{2}=$ Nilai rata-rata kuat tekan mortar komposisi 1 semen Portland

: 4 pasir

$\mathrm{SA}_{1}{ }^{2}=$ Varian kuat tekan mortar komposisi 1 kapur $: 2$ semen merah : 3 pasir

$\mathrm{SA}_{2}{ }^{2}=$ Varian kuat tekan mortar komposisi 1 kapur : 2 semen merah : 3 pasir

$\mathrm{n} \mathrm{A}_{1}=$ Jumlah sampel kuat tekan mortar komposisi 1 kapur : 2 semen merah : 3 pasir

$\mathrm{n}_{2}=$ Jumlah sampel kuat tekan mortar komposisi 1 semen Portland : 4 pasir

Perumusan hipotesis :

Ho : $\quad \mu A_{1}=\mu A_{2} \quad$ (Hipotesis ditolak)

$\mathrm{H}_{1}: \quad \mu \mathrm{A}_{1}<\mu \mathrm{A}_{2} \quad$ (Hipotesis diterima)

Kriteria pengujian : Tolak $\mathrm{Ho}$ jika $\mathrm{t}_{\text {hitung }} \leq$ Harga $_{\mathrm{t}_{\text {-a }}}$ atau $\mathrm{t}_{\text {tabel }}$ didapat dari distribusi $\mathrm{t}$ dengan derajat kebebasan $(\mathrm{dk})=\mathrm{N} \mathrm{A}_{1}+\mathrm{N} \mathrm{A}_{2}-2$ dan peluang $=(1-\alpha)$. Taraf signifikan $\alpha=0,01$

\section{Teknik Analisis Data Kuat Geser Mortar Pasangan Bata}

Sebelum melakukan uji hipotesis, data kuat geser mortar pasangan bata harus diuji kenormalannya menggunakan uji Lilliefors dan pengujian homogenitas menggunakan uji $\mathrm{F}$. Setelah kedua persyaratan terpenuhi, selanjutnya dilakukan pengujian hipotesis menggunakan uji t "kesamaan dua rata-rata satu pihak" dengan taraf signifikan $\alpha=0,01$

Pengujian hipotesis statistiknya ditentukan dengan :

a. $\mathrm{Ho}_{0}: \mu \mathrm{A}_{1}=\mu \mathrm{A}_{2}$

Artinya tidak terdapat perbedaan kuat geser mortar pasangan bata antara mortar komposisi 1 kapur : 2 semen merah : 3 pasir dengan mortar komposisi 1 semen Portland : 4 pasir.

b. $H_{1}: \mu A_{1}<\mu A_{2}$ 
Artinya nilai kuat geser mortar pasangan bata komposisi 1 kapur : 2 semen merah : 3 pasir lebih kecil daripada nilai kuat tekan mortar komposisi 1 semen portland : 4 pasir.

Keterangan :

$\mu A_{1} \quad$ : Nilai rata-rata kuat geser mortar pasangan bata komposisi 1 kapur : 2 semen merah : 3 pasir

$\mu \mathrm{A}_{2} \quad$ : Nilai rata-rata kuat geser mortar pasangan bata komposisi 1 semen portland : 4 pasir

Rumus uji t "kesamaan rata-rata satu pihak" adalah sebagai berikut : (Sujana, 2001)

$$
\mathrm{t}=\frac{\mathrm{XA}_{1} \mathrm{XA}_{2}}{\sqrt{\frac{\left(\mathrm{nA}_{1} 1\right) \mathrm{SA}_{1}^{2}+\left(\mathrm{nA}_{2} 1\right) \mathrm{SA}_{2}^{2}}{\mathrm{nA}_{1}+\mathrm{nA}_{2} 2}} \frac{\frac{1}{\mathrm{nA}_{1}}+\frac{1}{\mathrm{nA}_{2}}}{}}
$$

Keterangan :

$\mathrm{t}=\mathrm{t}$ hitung

$\mathrm{XA}_{1}=$ Nilai rata-rata kuat geser mortar pasangan bata komposisi

1 kapur : $2 \quad$ semen merah : 3 pasir

$\mathrm{XA}_{2}=$ Nilai rata-rata kuat geser mortar pasangan bata komposisi 1 semen Portland : 4 pasir

$\mathrm{SA}_{1}{ }^{2}=$ Varian kuat geser mortar pasangan bata komposisi 1 kapur : 2 semen merah : 3 pasir

$\mathrm{SA}_{2}{ }^{2}=$ Varian kuat geser mortar pasangan bata komposisi 1 kapur : 2 semen merah : 3 pasir

$\mathrm{n} \mathrm{A}_{1} \quad=$ Jumlah sampel kuat geser mortar pasangan bata komposisi 1 kapur : 2 semen merah : 3 pasir

$\mathrm{n} \mathrm{A}_{2} \quad=$ Jumlah sampel kuat geser mortar pasangan bata komposisi 1 semen Portland : 4 pasir

Perumusan hipotesis :

Ho : $\quad \mu A_{1}=\mu A_{2} \quad$ (Hipotesis ditolak)

$\mathrm{H}_{1}: \quad \mu \mathrm{A}_{1}<\mu \mathrm{A}_{2} \quad$ (Hipotesis diterima)

Kriteria pengujian : Tolak Ho jika thitung $\leq$ Harga $t_{1-a}$ atau $t_{\text {tabel }}$ didapat dari distribusi $t$ dengan derajat kebebasan $(\mathrm{dk})=\mathrm{N} A_{1}+\mathrm{NA}_{2}-2$ dan peluang $=(1-\mathrm{a})$. Taraf signifikan $\mathrm{a}=0,01$ 


\section{HASIL DAN PEMBAHASAN}

\section{A. Deskripsi Data}

Berdasarkan hasil penelitian yang telah dilakukan dengan beberapa perlakuan benda uji, yaitu untuk kelompok benda uji A (mortar dengan komposisi 1 Kapur : 2 Semen Merah : 3 Pasir) dan kelompok benda uji B (mortar dengan komposisi 1 PC : 4 Pasir) yang masing-masing diberikan perlakuan uji kuat tekan dan uji kuat geser.

Sebelum benda uji diuji kuat tekan dan kuat gesernya, benda uji tersebut dilakukan pengujian berupa pengujian ukuran. Untuk benda uji kuat tekan dilakukan pengujian ukuran yang meliputi luas penampang dan berat. Dan untuk benda uji kuat geser hanya dilakukan pengujian berat. Setelah pengujian ukuran selesai dilakukan, baru dilakukan pengujian kuat tekan dan kuat geser. Secara lengkap hasil penelitian dapat dilihat sebagai berikut yang disertai dengan hasil pengujian bahan.

1. Hasil pengujian bahan

Hasil pengujian bahan yang dilakukan terhadap bahan dasar pembuatan mortar dapat dilihat pada tabel 6 berikut ini :

Tabel 6. Hasil Pengujian Bahan

\begin{tabular}{|c|c|c|c|}
\hline No & Bahan & Pengujian & Hasil \\
\hline 1. & $\begin{array}{l}\text { Semen Portland } \\
\text { (cap Tiga Roda } \\
\text { tipe I) }\end{array}$ & $\begin{array}{l}\text { Tidak dilakukan pengujian } \\
\text { (karena telah memenuhi } \\
\text { persyaratan) }\end{array}$ & - \\
\hline 2. & Semen Merah & $\begin{array}{l}\text { Kehalusan dengan ukuran } \\
\text { ayakan No. } 200\end{array}$ & $100 \%$ lolos \\
\hline 3. & Kapur & $\begin{array}{l}\text { Kehalusan dengan ukuran } \\
\text { ayakan No. } 200\end{array}$ & $100 \%$ lolos \\
\hline 4. & $\begin{array}{l}\text { Agregat halus } \\
\text { (pasir Galunggung) }\end{array}$ & $\begin{array}{l}\text { Kadar Lumpur } \\
\text { Zat organis } \\
\text { Modulus Halus Butir (MHB) } \\
\text { Indeks kekerasan butiran } \\
\text { Berat jenis dan penyerapan air } \\
\text { BJ curah / kering } \\
\text { BJ kering permukaan jenuh } \\
\text { (SSD) }\end{array}$ & $\begin{array}{l}2,16 \% \\
\text { Warna kuning muda } \\
2,3602 \\
2,17 \\
2,216 \\
2,392\end{array}$ \\
\hline
\end{tabular}




\begin{tabular}{|c|c|c|c|}
\hline No & Bahan & Pengujian & Hasil \\
\hline & & BJ semu / nyata & 2,689 \\
\hline & & Penyerapan air & $7,944 \%$ \\
\hline 5. & $\begin{array}{l}\text { Air } \\
\text { (Air PAM / tawar) }\end{array}$ & $\begin{array}{l}\text { Tidak dilakukan pengujian } \\
\text { (karena telah memenuhi } \\
\text { persyaratan) }\end{array}$ & - \\
\hline
\end{tabular}

1. Hasil pengujian ukuran benda uji mortar pasangan bata

a. Ukuran benda uji kuat tekan mortar pasangan bata

Untuk benda uji kuat tekan, dilakukan pengujian ukuran yang meliputi ukuran luas penampang (panjang dan lebar) dan berat benda uji. Data-data hasil pengujian ukuran benda uji kuat tekan mortar pasangan bata untuk tiap kelompok dapat dilihat pada tabel 7 dibawah ini :

Tabel 7. Hasil Pengujian Ukuran Benda Uji Kuat Tekan Mortar

\begin{tabular}{|c|c|c|c|}
\hline \multirow{2}{*}{$\begin{array}{c}\text { Kelompok } \\
\text { Benda Uji }\end{array}$} & \multicolumn{3}{|c|}{ Ukuran rata-rata benda uji } \\
\cline { 2 - 4 } & Panjang (cm) & Lebar (cm) & Berat (kg) \\
\hline$A_{1}$ & 5,10 & 5,08 & 1,58 \\
$B_{1}$ & 5,10 & 5,12 & 1,93 \\
\hline
\end{tabular}

b. Ukuran benda uji kuat geser mortar

Untuk benda uji kuat geser, dilakukan pengujian ukuran yang meliputi ukuran luas bidang geser dan berat benda uji. Data-data hasil pengujianukuran benda uji kuat geser mortar pasangan bata untuk tiap kelompok dapat dilihat pada tabel 8 dibawah ini :

Tabel 8. Hasil Pengujian Ukuran Benda Uji Kuat Geser Mortar Pasangan Bata

\begin{tabular}{|c|c|c|}
\hline \multirow{2}{*}{$\begin{array}{c}\text { Kelompok } \\
\text { Benda Uji }\end{array}$} & \multicolumn{2}{|c|}{ Ukuran rata-rata benda uji } \\
\cline { 2 - 3 } & Luas bidang geser (cm) & Berat (kg) \\
\hline$A_{2}$ & 226,412 & 7,725 \\
$B_{2}$ & 226,412 & 8,29 \\
\hline
\end{tabular}


2. Hasil pengujian kuat tekan benda uji mortar pasangan bata

Data hasil pengujian kuat tekan didapat dari hasil pengujian setiap benda uji. Nilai kuat tekan merupakan hasil bagi antara beban maksimum yang diterima oleh benda uji dengan luas penampang benda uji. Beban maksimum ditunjukkan oleh jarum penunjuk pada mesin uji tekan. Data hasil pengujian kuat tekan mortar pasangan bata untuk tiap kelompok benda uji dapat dilihat pada tabel 9 berikut ini :

Tabel 9. Hasil Pengujian Kuat Tekan Mortar

\begin{tabular}{|c|c|c|c|}
\hline \multirow{2}{*}{$\begin{array}{c}\text { Kelompok } \\
\text { Benda Uji }\end{array}$} & Minimum & Maksimum & Rata-rata \\
\cline { 2 - 4 } & 6,68 & 8,50 & 7,58 \\
$\mathrm{~A}_{1}$ & 29,70 & 35,37 & 32,34 \\
\hline
\end{tabular}

Dari tabel tersebut dapat dilihat bahwa hasil pengujian kuat tekan untuk mortar pasangan bata dengan komposisi 1 kapur : 2 semen merah : 3 pasir mempunyai nilai kuat tekan yang lebih rendah dibandingkan dengan mortar pasangan bata dengan komposisi $1 \mathrm{PC}: 4$ pasir.

3. Hasil pengujian kuat geser benda uji mortar pasangan bata

Data hasil pengujian kuat geser didapat dari hasil pengujian setiap benda uji. Nilai kuat geser adalah gaya geser persatuan luas bidang geser. Beban maksimum ditunjukkan oleh jarum penunjuk pada mesin uji geser. Data hasil pengujian kuat geser mortar pasangan bata untuk tiap kelompok benda uji dapat dilihat pada tabel 10 berikut ini :

Tabel 10. Hasil Pengujian Kuat Geser Mortar Pasangan Bata

\begin{tabular}{|c|c|c|c|}
\hline \multirow{2}{*}{$\begin{array}{c}\text { Kelompok } \\
\text { Benda Uji }\end{array}$} & Minimum & Maksimum & Rata-rata \\
\cline { 2 - 4 } & 0,10 & 0,28 & 0,18 \\
$\mathrm{~A}_{2}$ & 0,17 & 0,69 & 0,45 \\
$\mathrm{~B}_{2}$ & & & \\
\end{tabular}

Dari tabel tersebut dapat dilihat bahwa hasil pengujian kuat geser untuk mortar pasangan bata dengan komposisi 1 kapur : 2 semen merah : 3 pasir mempunyai nilai kuat tekan yang lebih rendah dibandingkan dengan mortar pasangan bata dengan komposisi 1 PC : 4 pasir. 


\section{B. Pengujian Persyaratan Analisis}

Untuk memenuhi persyaratan dalam pengujian hipotesis, terlebih dahulu dilakukan pengujian persyaratan analisis yang meliputi uji normalitas dan homogenitas dari data kuat tekan dan kuat geser mortar pasangan bata.

1. Uji Normalitas

Untuk memenuhi syarat-syarat dalam pengujian hipotesis, telah dilakukan uji normalitas data dengan menggunakan uji lilliefors. Data yang dianalisa adalah data nilai kuat tekan dan kuat geser mortar pasangan bata dari masing-masing kelompok benda uji, yaitu kelompok A (mortar pasangan bata dengan komposisi 1 kapur : 2 semen merah : 3 pasir) dan kelompok B (mortar pasangan bata dengan komposisi 1 PC : 4 pasir).

a. Uji normalitas kuat tekan mortar pasangan bata

1. Uji normalitas kuat tekan mortar pasangan bata kelompok benda uji $A$

Hasil pengujian normalitas kuat tekan mortar pasangan bata komposisi 1 kapur : 2 semen merah : 3 pasir menghasilkan $L$ hitung $(L o)=0,1642$ dengan $n$ sampel $=10$ dan taraf nyata $a=0,01$ dari daftar nilai kritis uji lilliefors didapat nilai $L$ tabel $=0,294$. Ternyata $L o<L$ tabel, maka dapat disimpulkan bahwa data tersebut berdistribusi normal.

Rangkuman uji normalitas kuat tekan mortar pasangan bata komposisi 1 kapur : 2 semen merah : 3 pasir dapat dilihat pada tabel 11 dibawah ini.

Tabel 11. Uji Normalitas Kuat Tekan Mortar Komposisi 1 Kapur : 2 Semen Merah : 3 Pasir

\begin{tabular}{|c|c|c|c|}
\hline Subyek & Lo & L tabel & Hasil \\
\hline Kelompok benda uji $\mathrm{A}_{1}$ & & & Lo $<$ L tabel \\
(mortar komposisi & 0,1642 & 0,294 & $\begin{array}{c}\text { (distribusi } \\
\text { normal) }\end{array}$ \\
\hline kapur : 2 semen merah : 3 pasir) & & & \\
\hline
\end{tabular}

2. Uji normalitas kuat tekan mortar pasangan bata kelompok benda uji $B$ Hasil pengujian normalitas kuat tekan mortar pasangan bata komposisi 1 PC : 4 pasir menghasilkan $\mathrm{L}$ hitung $(\mathrm{L} o)=0,244$ dengan $\mathrm{n}$ sampel $=10$ dan taraf nyata $a=0,01$ dari daftar nilai kritis uji lilliefors didapat nilai $L$ tabel $=0,294$. Ternyata $\mathrm{L} 0<\mathrm{L}$ tabel, maka dapat disimpulkan bahwa data tersebut berdistribusi normal. 
Rangkuman uji normalitas kuat tekan mortar pasangan bata komposisi 1 PC : 4 pasir dapat dilihat pada tabel 12 dibawah ini.

Tabel 12. Uji Normalitas Kuat Tekan Mortar Komposisi 1 PC : 4 Pasir

\begin{tabular}{|c|c|c|c|}
\hline Subyek & Lo & L tabel & Hasil \\
\hline $\begin{array}{c}\text { Kelompok benda uji } \mathrm{B}_{1} \\
\text { (mortar komposisi }\end{array}$ & 0,244 & 0,294 & Lo $<$ L tabel \\
(distribusi \\
PC $: 4$ pasir) & & & normal) \\
\hline
\end{tabular}

b. Uji normalitas kuat geser mortar pasangan bata

1. Uji normalitas kuat geser mortar pasangan bata kelompok benda uji $A$ Hasil pengujian normalitas kuat geser mortar pasangan bata komposisi 1 kapur : 2 semen merah : 3 pasir menghasilkan $L$ hitung $($ Lo $)=0,285$ dengan $n$ sampel $=$ 10 dan taraf nyata $\alpha=0,01$ dari daftar nilai kritis uji lilliefors didapat nilai $L$ tabel $=0,294$. Ternyata $L o<L$ tabel, maka dapat disimpulkan bahwa data tersebut berdistribusi normal.

Rangkuman uji normalitas kuat geser mortar pasangan bata komposisi 1 kapur : 2 semen merah : 3 pasir dapat dilihat pada tabel 13 dibawah ini.

Tabel 13. Uji Normalitas Kuat Geser Mortar Pasangan Bata Komposisi 1 Kapur : 2 Semen Merah : 3 Pasir

\begin{tabular}{|c|c|c|c|}
\hline Subyek & Lo & L tabel & Hasil \\
\hline $\begin{array}{c}\text { Kelompok benda uji } \mathrm{A}_{2} \\
\text { (mortar pasangan bata } \\
\text { komposisi } 1 \text { kapur : } 2 \text { semen } \\
\text { merah : } 3 \text { pasir) }\end{array}$ & 0,285 & 0,294 & $\begin{array}{c}\text { Lo }<\text { L tabel } \\
\text { (distribusi normal) }\end{array}$ \\
\hline
\end{tabular}

2. Uji normalitas kuat geser mortar pasangan bata kelompok benda uji $B$ Hasil pengujian normalitas kuat geser mortar pasangan bata komposisi 1 PC : 4 pasir menghasilkan $\mathrm{L}$ hitung $(\mathrm{LO})=0,1664$ dengan $\mathrm{n}$ sampel $=10$ dan taraf nyata $a=0,01$ dari daftar nilai kritis uji lilliefors didapat nilai $L$ tabel $=0,294$. 
Ternyata Lo < L tabel, maka dapat disimpulkan bahwa data tersebut berdistribusi normal.

Rangkuman uji normalitas kuat geser mortar pasangan bata komposisi 1 PC : 4 pasir dapat dilihat pada tabel 14 dibawah ini.

Tabel 14. Uji Normalitas Kuat Geser Mortar Pasangan Bata Komposisi 1 Semen Portland : 4 Pasir

\begin{tabular}{|c|c|c|c|}
\hline Subyek & Lo & $L$ tabel & Hasil \\
\hline $\begin{array}{c}\text { Kelompok benda uji } \mathrm{B}_{2} \\
\text { (mortar pasangan bata } \\
\text { komposisi } \\
1 \mathrm{PC}: 4 \text { pasir) }\end{array}$ & 0,1664 & 0,294 & $\begin{array}{c}\text { Lo }<\text { L tabel } \\
\text { (distribusi } \\
\text { normal) }\end{array}$ \\
\hline
\end{tabular}

Secara keseluruhan, hasil uji normalitas kuat tekan dan kuat geser mortar pasangan bata dapat dilihat pada rangkuman tabel 15 dan 16 berikut

Tabel 15. Hasil Uji Normalitas Kuat Tekan Mortar Pasangan Bata

\begin{tabular}{|c|c|c|c|c|}
\hline No & Kelompok Benda Uji & Lo & L tabel & Hasil \\
\hline 1. & $\mathrm{~A}$ & 0,1642 & 0,294 & $\begin{array}{c}\text { Lo }<\text { L tabel } \\
\text { (Distribusi normal) }\end{array}$ \\
\hline 2. & $\mathrm{~B}$ & 0,224 & 0,294 & \\
\hline
\end{tabular}

Tabel 16. Hasil Uji Normalitas Kuat Geser Mortar Pasangan Bata

\begin{tabular}{|c|c|c|c|c|}
\hline No & Kelompok Benda Uji & Lo & L tabel & Hasil \\
\hline 1. & A & 0,285 & 0,294 & $\begin{array}{c}\text { Lo }<\text { L tabel } \\
\text { (Distribusi normal) }\end{array}$ \\
\hline 2. & B & 0,166 & 0,294 & \\
\hline
\end{tabular}

\section{Uji Homogenitas}

Setelah melakukan uji normalitas, maka selanjutnya dilakukan pengujian homogenitas dengan menggunakan uji kesamaan dua varians. Data yang diuji adalah data kuat tekan dan kuat geser mortar pasangan bata dari masing-masing kelompok benda uji. 
a. Uji homogenitas kuat tekan mortar pasangan bata

Dari perhitungan diperoleh $\mathrm{F}$ hitung $=1,14$ dengan taraf nyata $a=0,01$ didapat nilai $F$ tabel $0,314<F<3,18$ dimana nilai $F$ hitung berada dalam daerah penerimaan Ho. Maka dapat disimpulkan bahwa data adalah homogen.

b. Uji homogenitas kuat tekan mortar pasangan bata

Dari perhitungan diperoleh $F$ hitung $=0,422$ dengan taraf nyata $\alpha=0,01$ didapat nilai $\mathrm{F}$ tabel $0,314<\mathrm{F}<3,18$ dimana nilai $\mathrm{F}$ hitung berada dalam daerah penerimaan $\mathrm{Ho}$. Maka dapat disimpulkan bahwa data adalah homogen.

\section{Pengujian Hipotesis dan Hasil Penelitian}

Pengujian hipotesis dilakukan dengan menggunakan kesamaan dua rata-rata uji - t satu pihak.

1. Pengujian hipotesis dan kuat tekan mortar pasangan bata

Dari hasil perhitungan diperoleh $\mathrm{t}$ hitung $=-39,663$. Sementara untuk $\mathrm{t}$ tabel didapat dari tabel distribusi $t$ (terlampir) dengan derajat kebebasan $(\mathrm{dk})=18$ dan peluang $(1-\alpha)=0,09$ didapat $t$ tabel sebesar $-2,55$

Karena $t$ hitung $(-39,663)<t$ tabel $(-2,55)$, maka berdasarkan kriteria pengujian Ho ditolak. Berarti hipotesis penelitian diterima.

Hasil penelitian adalah nilai kuat tekan mortar pasangan bata komposisi 1 kapur : 2 semen merah : 3 pasir lebih kecil dari pada kuat tekan mortar pasangan bata komposisi 1 semen Portland : 4 pasir.

Rangkuman hasil uji hipotesis antara nilai kuat tekan mortar pasangan bata komposisi 1 kapur : 2 semen merah : 3 pasir dan nilai kuat tekan mortar pasangan bata komposisi 1 semen Portland : 4 pasir dapat dilihat pada tabel 17 berikut ini.

Tabel 17. Hasil Uji Hipotesis Kuat Tekan Mortar Pasangan Bata

\begin{tabular}{|c|c|c|}
\hline $\mathbf{t}$ hitung & $\mathbf{t}$ tabel & Hasil \\
\hline & & t hitung $<\mathrm{t}$ tabel \\
$-39,663$ & $-2,55$ & Ho ditolak \\
& & Hipotesis diterima \\
\hline
\end{tabular}


2. Pengujian hipotesis dan kuat geser mortar pasangan bata

Dari hasil perhitungan diperoleh $\mathrm{t}$ hitung $=-2,38$. Sementara untuk $\mathrm{t}$ tabel didapat dari tabel distribusi $\mathrm{t}$ (terlampir) dengan derajat kebebasan $(\mathrm{dk})=18$ dan peluang $(1-\mathrm{a})=0,09$ didapat $\mathrm{t}$ tabel sebesar $-2,55$

Karena $t$ hitung $(-2,38)<t$ tabel $(-2,55)$, maka berdasarkan kriteria pengujian Ho ditolak. Berarti hipotesis penelitian diterima.

Hasil penelitian adalah nilai kuat geser mortar pasangan bata komposisi 1 kapur : 2 semen merah : 3 pasir lebih kecil dari pada nilai kuat geser mortar pasangan bata komposisi 1 semen Portland : 4 pasir.

Rangkuman hasil uji hipotesis antara nilai kuat geser mortar pasangan bata komposisi 1 kapur : 2 semen merah : 3 pasir dan nilai kuat tekan mortar pasangan bata komposisi 1 semen Portland : 4 pasir dapat dilihat pada tabel 17 berikut ini.

Tabel 17. Hasil Uji Hipotesis Kuat Geser Mortar Pasangan Bata

\begin{tabular}{|c|c|c|}
\hline $\mathbf{t}$ hitung & $\mathbf{t}$ tabel & Hasil \\
\hline \multirow{2}{*}{$-2,38$} & & t hitung $<\mathrm{t} \mathrm{tabel}$ \\
& $-2,55$ & Ho ditolak \\
& & Hipotesis diterima \\
\hline
\end{tabular}

\section{Pembahasan Hasil Penelitian}

Dilihat dari hasil penelitian dan pengujian hipotesis secara statistik, adalah sebagai berikut :

1. Mortar komposisi 1 kapur : 2 semen merah : 3 pasir menghasilkan kuat tekan yang lebih rendah dibandingkan dengan mortar pasangan bata komposisi 1 semen Portland : 4 pasir

2. Mortar pasangan bata komposisi 1 kapur : 2 semen merah : 3 pasir menghasilkan kuat geser yang lebih rendah dibandingkan dengan mortar pasangan bata komposisi 1 semen Portland : 4 pasir

3. Ketika benda uji ditekan, mortar pasangan bata komposisi 1 kapur : 2 semen merah : 3 pasir didahului pola retak yang lebih halus sabelum mortar menjadi hancur dibandingkan dengan mortar pasangan bata komposisi 1 semen Portland : 4 pasir. Hal ini disebabkan karena kandungan kapur memberikan elastisitas pada mortar yang dihasilkan 
4. Mortar pasangan bata komposisi 1 kapur : 2 semen merah : 3 pasir menghasilkan berat mortar yang lebih ringan dibandingkan dengan mortar pasangan bata komposisi 1 semen Portland : 4 pasir. Hal ini disebabkan karena perbandingan bahan pengisi yaitu pasir yang lebih banyak terdapat dalam mortar pasangan bata komposisi 1 semen Portland : 4 pasir

5. Sesudah mengeras, mortar pasangan bata komposisi 1 kapur : 2 semen merah : 3 pasir menghasilkan permukaan mortar yang lebih halus dibandingkan dengan mortar pasangan bata komposisi 1 semen Portland : 4 pasir. Hal ini disebabkan karena perbandingan bahan yang halus yaitu kapur, semen merah dan semen Portland lebih banyak terdapat didalam mortar pasangan bata komposisi 1 kapur : 2 semen merah : 3 pasir

6. Pemakaian kapur dalam adukan menyebabkan adukan menjadi lebih plastis dan memiliki waktu setting yang lama dalam pelaksanaan, sehingga mortar pasangan bata komposisi 1 kapur : 2 semen merah : 3 pasir mempunyai workability yang lebih baik dibandingkan dengan mortar pasangan bata komposisi 1 kapur : 4 pasir

Hal - hal tersebut disebabkan karena komposisi kimia dari bahan baku yang menyusun mortar itu sendiri. Semen Portland banyak mengandung senyawa kimia yang menguntungkan untuk mortar dan proses pembuatannya menggunakan teknologi canggih. Sedangkan semen merah dan kapur merupakan bahan yang diambil dari alam tanpa ada penambahan zat kimia dan proses pembuatannya menggunakan cara yang masih tradisional.

\section{KESIMPULAN}

Berdasarkan hasil penelitian, maka kesimpulan yang dapat ditarik adalah sebagai berikut :

1. Mortar komposisi 1 kapur : 2 semen merah : 3 pasir menghasilkan kuat tekan yang lebih rendah dibandingkan dengan mortar pasangan bata komposisi 1 semen Portland : 4 pasir

2. Mortar pasangan bata komposisi 1 kapur : 2 semen merah : 3 pasir menghasilkan kuat geser yang lebih rendah dibandingkan dengan mortar pasangan bata komposisi 1 semen Portland : 4 pasir 
3. Ketika benda uji ditekan, mortar pasangan bata komposisi 1 kapur : 2 semen merah : 3 pasir didahului pola retak yang lebih halus sabelum mortar menjadi hancur dibandingkan dengan mortar pasangan bata komposisi 1 semen Portland : 4 pasir. Hal ini disebabkan karena kandungan kapur memberikan elastisitas pada mortar yang dihasilkan

4. Mortar pasangan bata komposisi 1 kapur : 2 semen merah : 3 pasir menghasilkan berat mortar yang lebih ringan dibandingkan dengan mortar pasangan bata komposisi 1 semen Portland : 4 pasir. Hal ini disebabkan karena perbandingan bahan pengisi yaitu pasir yang lebih banyak terdapat dalam mortar pasangan bata komposisi 1 semen Portland : 4 pasir

5. Sesudah mengeras, mortar pasangan bata komposisi 1 kapur : 2 semen merah : 3 pasir menghasilkan permukaan mortar yang lebih halus dibandingkan dengan mortar pasangan bata komposisi 1 semen Portland : 4 pasir. Hal ini disebabkan karena perbandingan bahan yang halus yaitu kapur, semen merah dan semen Portland lebih banyak terdapat didalam mortar pasangan bata komposisi 1 kapur : 2 semen merah : 3 pasir

6. Pemakaian kapur dalam adukan menyebabkan adukan menjadi lebih plastis dan memiliki waktu setting yang lama dalam pelaksanaan, sehingga mortar pasangan bata komposisi 1 kapur : 2 semen merah : 3 pasir mempunyai workability yang lebih baik dibandingkan dengan mortar pasangan bata komposisi 1 kapur : 4 pasir

\section{DAFTAR PUSTAKA}

Beall Christine, Masonry Design and Detailing for Architects, Engineers and Builders, New York :McGraw Hill Book Company, 1987), h. 91

Departemen Pekerjaan Umum, Spesifikasi Mortar Untuk Pekerjaan Pasangan SNI 03-68822002, (Republik Indonesia : Departemen Pekerjaan Umum), h. 209

Heinz Frick, IImu Konstruksi Bangunan I, (Yogyakarta : Kanisius, 1989), h. 3

Sudjana, Metoda Statistika, (Bandung : Tarsito, 2001), h. 240 